\title{
Expansão pentecostal no Brasil: o caso da Igreja Universal
}

\author{
RICARDO MARIANO
}

$\mathrm{F}$ ORMADO No início do século XX nos Estados Unidos, o pentecostalismo vem crescendo em vários países em desenvolvimento do Sul do Pacífico, da África, do Leste e do Sudeste da Ásia, sobretudo da América Latina, onde o Brasil se destaca abrigando cerca de trinta milhões de evangélicos ${ }^{1}$.

No Brasil, a expansão pentecostal não é recente nem episódica. Ocorre de modo constante já há meio século, o que permitiu que o pentecostalismo se tornasse o segundo maior grupo religioso do país. Mas seu avanço não é expressivo apenas nos planos religioso e demográfico. Estende-se pelos campos midiático, político partidário, assistencial, editorial e de produtos religiosos. Seus adeptos não se restringem mais somente aos estratos pobres da população, encontrandose também nas classes médias, incluindo empresários, profissionais liberais, atletas e $\operatorname{artistas}^{2}$. Ao lado e por meio disso, o pentecostalismo vem conquistando crescente visibilidade pública, legitimidade e reconhecimento social e deitando e aprofundando raízes nos mais diversos estratos e áreas da sociedade brasileira.

Conforme os Censos Demográficos do IBGE, os evangélicos perfaziam apenas $2,6 \%$ da população brasileira na década de 1940 . Avançaram para $3,4 \% \mathrm{em}$ $1950,4 \%$ em 1960, 5,2\% em 1970, 6,6\% em 1980, 9\% em 1991 e $15,4 \%$ em 2000, ano em que somava 26.184 .941 de pessoas. $\mathrm{O}$ aumento de 6,4 pontos percentuais e a taxa de crescimento médio anual de $7,9 \%$ do conjunto dos evangélicos entre 1991 e 2000 (taxa superior às obtidas nas décadas anteriores ${ }^{3}$ ) indicam que a expansão evangélica acelerou-se ainda mais no último decênio do século XX.

Os evangélicos estão distribuídos desigualmente pelas regiões brasileiras. O Nordeste, com apenas 10,4\% de evangélicos, continua sendo o principal reduto católico e, por isso, a região de mais difícil penetração protestante, enquanto o Norte e o Centro-Oeste, com 18,3\% e 19,1\%, respectivamente, constituem as regiões em que esses religiosos mais se expandem. Apesar de reproduzir a média brasileira, o Sul, onde se concentra o luteranismo, tem apresentado os mais baixos índices de crescimento evangélico, sendo que em alguns estados ocorre perda relativa de crentes na população. O Sudeste, com 17,7\%, mantém-se como um dos mais importantes pólos da expansão evangélica.

Os principais responsáveis por tal sucesso proselitista foram os pentecostais, que cresceram $8,9 \%$ anualmente, enquanto os protestantes históricos atingiram a cifra de $5,2 \%$. Com isso, os pentecostais, que perfazem dois terços dos evangéli- 
cos, saltaram de 8.768.929 para 17.617.307 adeptos (ou seja, de 5,6\% para 10,4\% da população) de 1991 a 2000, ao passo que os protestantes históricos passaram de 4.388.310 para 6.939.765 (de 3\% para 4,1\%) ${ }^{4}$. Embora as taxas de crescimento do protestantismo histórico sejam inferiores às do pentecostalismo, são muito elevadas, sobretudo tendo em vista que na década anterior o protestantismo apresentou taxa de crescimento anual negativa $(-0,4)$. Isto provavelmente derivou de falhas do Censo de 1991, já que não ocorreram mudanças significativas nas igrejas protestantes de uma década para outra que permitam explicar e justificar tamanha disparidade dos dados.

As cifras mencionadas indicam que, nesse período, as igrejas pentecostais souberam aproveitar e explorar eficientemente, em benefício próprio, os contextos socioeconômico, cultural, político e religioso do último quarto de século no Brasil. Nesse sentido, cabe destacar, em especial, a agudização das crises social e econômica, o aumento do desemprego, o recrudescimento da violência e da criminalidade, o enfraquecimento da Igreja Católica, a liberdade e o pluralismo religiosos, a abertura política e a redemocratização do Brasil, a rápida difusão dos meios de comunicação de massa.

Outro aspecto a se ressaltar é que, apesar do elevado número de denominações pentecostais no país, Assembléia de Deus ${ }^{5}$, Congregação Cristã no Brasil e Universal do Reino de Deus, juntas, concentram 74\% dos pentecostais, ou treze milhões. Tamanha concentração institucional do pentecostalismo brasileiro, além de minimizar até certo ponto a importância da fragmentação denominacional ou do divisionismo organizacional desse movimento religioso, permite compreender porque a Assembléia de Deus e a Universal são as igrejas que logram, por exemplo, maior visibilidade pública e sucesso na política partidária ${ }^{6}$.

Os perfis socioeconômico e demográfico de pentecostais e protestantes são bastante distintos. Dados do último Censo revelam que a maioria dos pentecostais apresenta renda e escolaridade inferiores à média da população brasileira. Grande parte deles recebe até três salários mínimos e ocupa empregos domésticos, em geral modestos e precários, numa proporção bastante acima da média nacional. Em contraste, os protestantes históricos apresentam renda e escolaridade elevadas, ambas bem superiores à média brasileira, estando distribuídos mais nos níveis escolares de segundo grau, graduação e pós-graduação e nas faixas de renda entre seis e vinte salários mínimos. Pentecostais e protestantes são majoritariamente urbanos e apresentam maior proporção de mulheres que de homens. Quanto à cor dos fiéis, os primeiros sobressaem pela presença de pretos e pardos superior à média da população, enquanto os últimos pela maior proporção de brancos. Os pentecostais abrigam mais crianças e adolescentes do que adultos, enquanto os protestantes mais adultos e idosos do que jovens ${ }^{7}$, diferenças de perfil etário e de taxas de natalidade que, tal como ocorre nas comparações anteriores, refletem suas distinções de classe social. 
Antes de analisar a extraordinária expansão institucional da Igreja Universal do Reino de Deus, cabe discorrer, de modo sucinto, sobre a evolução histórica e a classificação do pentecostalismo no Brasil.

O primeiro missionário pentecostal chegou ao Brasil há 94 anos. Desde então, foram criadas centenas de igrejas, tornando este movimento religioso complexo e diversificado. Para tornar inteligível sua evolução e diversidade interna, pesquisadores ${ }^{8}$ passaram a ordenar este campo religioso em três grupos e classificálos com base em critérios históricos (ou periodização) de implantação de igrejas, em distinções teológicas e comportamentais.

O pentecostalismo clássico abrange as igrejas pioneiras: Congregação Cristã no Brasil e Assembléia de Deus. A Congregação Cristã foi fundada por um italiano em 1910, na capital paulista, e a Assembléia de Deus, por dois suecos, em Belém do Pará, em 1911. Embora europeus, os três missionários converteram-se ao pentecostalismo nos Estados Unidos, de onde vieram para evangelizar o Brasil. De início, na condição de grupos religiosos minoritários em terreno "hostil", ambas as igrejas caracterizaram-se pelo anticatolicismo, por radical sectarismo e ascetismo de rejeição do mundo. No plano teológico, enfatizaram o dom de línguas (glossolalia), seguindo a ênfase doutrinária primitiva dessa religião. A Congregação Cristã, além de permanecer completamente isolada das demais igrejas e organizações pentecostais, manteve-se mais apegada a certos traços sectários, enquanto a Assembléia de Deus mostrou, sobretudo nas duas últimas décadas, maior disposição para adaptar-se a mudanças em processo no pentecostalismo e na sociedade brasileira.

O segundo grupo de igrejas implantado no Brasil, que não obteve nomenclatura consensual na literatura acadêmica, começou na década de 1950, quando dois missionários norte-americanos da International Church of The Foursquare Gospel criaram, em São Paulo, a Cruzada Nacional de Evangelização. Por meio dela, iniciaram o evangelismo focado na pregação da cura divina, que atraiu multidões às concentrações evangelísticas na capital paulista e acelerou a expansão do pentecostalismo brasileiro. Em 1953, fundaram a Igreja do Evangelho Quadrangular no Estado de São Paulo. No rastro de suas atividades de evangelização, surgiram Brasil Para Cristo (1955, SP), Deus é Amor (1962, SP) e Casa da Bênção $(1964, M G)^{9}$. Os missionários da Quadrangular conferiram ênfase teológica à cura divina, seguindo o bem-sucedido movimento de cura propagado nos Estados Unidos durante a Segunda Guerra Mundial. Como estratégia proselitista, além da ênfase na cura, essa vertente pentecostal notabilizou-se pelo intenso uso do rádio e pela pregação itinerante com o emprego de tendas de lona.

O neopentecostalismo teve início na segunda metade dos anos de 1970. Cresceu, ganhou visibilidade e se fortaleceu no decorrer das décadas seguintes. A Universal do Reino de Deus (1977, RJ), a Internacional da Graça de Deus (1980, RJ), a Comunidade Evangélica Sara Nossa Terra (1976, GO) e a Renascer em Cristo (1986, SP), fundadas por pastores brasileiros, constituem as principais 
igrejas neopentecostais do país. No plano teológico, caracterizam-se por enfatizar a guerra espiritual contra o Diabo e seus representantes na terra, por pregar a Teologia da Prosperidade, difusora da crença de que o cristão deve ser próspero, saudável, feliz e vitorioso em seus empreendimentos terrenos, e por rejeitar usos e costumes de santidade pentecostais, tradicionais símbolos de conversão e pertencimento ao pentecostalismo.

Encabeçado pela Igreja Universal, o neopentecostalismo é a vertente pentecostal que mais cresce atualmente e a que ocupa maior espaço na televisão brasileira, seja como proprietária de emissoras de TV, seja como produtora e difusora de programas de televangelismo. Do ponto de vista comportamental, é a mais liberal. Haja vista que suprimiu características sectárias tradicionais do pentecostalismo e rompeu com boa parte do ascetismo contracultural tipificado no estereótipo pelo qual os crentes eram reconhecidos e, volta e meia, estigmatizados. De modo que seus fiéis foram liberados para vestir roupas da moda, usar cosméticos e demais produtos de embelezamento, freqüentar praias, piscinas, cinemas, teatros, torcer para times de futebol, praticar esportes variados, assistir a televisão e vídeos, tocar e ouvir diferentes ritmos musicais. Práticas que, nos últimos anos, também foram sendo paulatinamente permitidas por igrejas pentecostais das vertentes precedentes, com exceção da Deus é Amor, que manteve incólume a velha rigidez ascética. Em todas as vertentes permanece, porém, a interdição ao consumo de álcool, tabaco e drogas e ao sexo extraconjugal e homossexual.

Sem perder necessariamente sua distintividade religiosa, as igrejas neopentecostais revelam-se, entre as pentecostais, as mais inclinadas a acomodarem-se à sociedade abrangente e a seus valores, interesses e práticas. Daí seus cultos basearem-se na oferta especializada de serviços mágico-religiosos, de cunho terapêutico e taumatúrgico, centrados em promessas de concessão divina de prosperidade material, cura física e emocional e de resolução de problemas familiares, afetivos, amorosos e de sociabilidade. Oferta sob medida para atender a demandas de quem crê que pode se dar bem nesta vida e neste mundo recorrendo a instituições intermediárias de forças sobrenaturais. Com tal estratégia, empregada também nos evangelismos pessoal e eletrônico, atraem e convertem majoritariamente indivíduos dos estratos pobres da população, muitos deles carentes e em crise pessoal, geralmente mais vulneráveis a esse tipo de prédica. Não obstante o apelo sistemático à oferta de soluções mágicas configure uma prática usual nas religiões populares no Brasil, observa-se que, no caso neopentecostal, tal procedimento, diferentemente do que ocorre no catolicismo popular, por exemplo, é orquestrado pelas lideranças eclesiásticas e posto em ação nos cultos oficiais e por meio do evangelismo eletrônico.

\section{Igreja Universal do Reino de Deus}

A Igreja Universal foi fundada em 1977 na zona norte da cidade do Rio de Janeiro, onde antes funcionava uma pequena funerária. Em menos de três déca- 
das se transformou no mais surpreendente e bem-sucedido fenômeno religioso do país, atuando de forma destacada no campo político ${ }^{10}$ e na mídia eletrônica. Nenhuma outra igreja evangélica cresceu tanto em tão pouco tempo no Brasil. Seu crescimento institucional foi acelerado desde o início. Em 1985, com oito anos de existência, já contava com 195 templos em catorze Estados e no Distrito Federal. Dois anos depois, eram 356 templos em dezoito Estados. Em 1989, ano em que começou a negociar a compra da Rede Record, somava 571 locais de culto $^{11}$. Entre 1980 e 1989, o número de templos cresceu $2.600 \%$. Nos primeiros anos, sua distribuição geográfica concentrou-se nas regiões metropolitanas do Rio de Janeiro, de São Paulo e de Salvador. Em seguida, expandiu-se pelas demais capitais ${ }^{12}$ e grandes e médias cidades. Na década de 1990, passou a cobrir todos os Estados do território brasileiro, período no qual logrou taxa de crescimento anual de $25,7 \%$, saltando de 269 mil (dado certamente subestimado) para 2.101.887 adeptos no Brasil, de onde se espraiou para mais de oitenta países ${ }^{13}$. Em todos eles, conquista adeptos majoritariamente entre os estratos mais pobres e menos escolarizados da população.

Um dos principais responsáveis pela constituição desse verdadeiro império religioso, o fluminense Edir Bezerra Macedo, seu líder e fundador, tornou-se crente evangélico aos dezoito anos, ingressando na Igreja de Nova Vida por meio da influência de uma irmã. Antes era católico e freqüentava a Umbanda. Permaneceu na Nova Vida de 1963 até 1975, quando, contrariado com seu elitismo de classe média, deixou-a para fundar a Cruzada do Caminho Eterno. Dois anos depois, nova cisão: saiu para formar, junto com outros crentes, a Universal do Reino de Deus ${ }^{14}$.

Desde o princípio, Macedo adotou a evangelização eletrônica como carrochefe de sua estratégia proselitista. E por meio da popularidade adquirida como apresentador de um programa religioso na Rádio Metropolitana, conseguiu suplantar R. R. Soares na liderança da igreja ${ }^{15}$. Em 1980, implementou o governo eclesiástico episcopal, no qual assumiu o posto de bispo primaz e o cargo vitalício de secretário-geral do presbitério, cargo do qual renunciaria em 1990 para evitar que eventuais sanções penais contra si atingissem a igreja.

Cabe fazer um parêntese para frisar que tal temor revelou-se nada exagerado ou fantasioso, uma vez que, durante toda a primeira metade dos anos de 1990, a igreja e seus dirigentes estiveram no centro de intensas controvérsias, envolvendo os mais diferentes agentes dos campos religioso, empresarial, midiático, policial, judicial e político. Métodos heterodoxos de arrecadação, vilipêndio a culto religioso, agressão física contra adeptos dos cultos afro-brasileiros e investimentos empresariais ${ }^{16}$ milionários, em especial a surpreendente compra da Rede Record por 45 milhões de dólares, em 1990, desencadearam uma série de críticas e acusações da grande imprensa e até de setores evangélicos ${ }^{17}$, inquéritos policiais e processos judiciais contra a Universal e seus líderes, um sem-número de vezes retratados em matérias jornalísticas como exploradores da credulidade dos po- 
bres. Para piorar a situação, em 1991, Carlos Magno de Miranda, ex-líder da igreja no Nordeste, acusou Edir Macedo de sonegar impostos, de envolvimento com o narcotráfico e de enviar ouro e dólares ilegalmente para o exterior, levando o bispo primaz a ter de depor na Justiça Federal. Em 24 de maio de 1992, acusado de cometer crimes de charlatanismo, curandeirismo e estelionato, Macedo foi preso pela 91 a Delegacia de Polícia de São Paulo, onde ficou encarcerado numa cela especial por doze dias até ser solto mediante habeas corpus. Na véspera do Natal de 1995, Carlos Magno voltou à carga tornando público um vídeo inédito, gravado em 1990, em que Edir Macedo aparecia rindo enquanto contava dinheiro num templo em Nova York, divertindo-se num iate em Angra dos Reis e instruindo, durante intervalo de uma partida de futebol, pastores a serem mais eficazes na coleta de dízimos e ofertas. A exibição do vídeo provocou uma das maiores controvérsias religiosas dos anos de 1990 no Brasil, resultando na mobilização de polícia e Receita Federal, Justiça, Previdência Social, Procuradoria da República e Interpol para investigar a Igreja Universal e seus líderes, que, em resposta, atacaram a Rede $\mathrm{Globo}^{18}$, reclamaram de perseguição religiosa e realizaram grandes manifestações públicas de desagravo. Macedo e os bispos da igreja só conseguiram se afastar das páginas e manchetes policiais no final dos anos de 1990 em diante.

Nesse período conturbado da história da Universal, Macedo procurou rarear sua presença no Brasil e estendê-la nos Estados Unidos, onde fundara uma filial em $1986^{19}$. Decidiu, então, nomear o pastor Renato Suhett para substituí-lo na direção da igreja no Brasil, para logo em seguida enfraquecê-lo, ao transferir funções administrativas a outros bispos e dividir o poder eclesiástico em quatro regiões no país. Em meados da década de 1990, consagrou dezenas de novos bispos para assumir funções de direção em nível regional, estadual e nacional. Para evitar cismas, reestruturou o poder eclesiástico, criando três instâncias hierárquicas: Conselho Mundial de Bispos, Conselho de Bispos do Brasil e Conselho de Pastores. Com isso, a igreja manteve os princípios de verticalidade e concentração de seu governo episcopal, que continuou encimado por Macedo.

Como fator de expansão denominacional, o governo verticalizado e centralizado da Universal, com efeito, é tão ou mais importante que a decantada competência religiosa, gerencial e empresarial de sua liderança eclesiástica. Nesse sentido, cumpre destacar que o governo episcopal tal como exercido pela igreja reforça a unidade e a coesão denominacional, dinamiza o processo decisório, agiliza a transmissão das ordens superiores e a realização dos trabalhos administrativos, organizacionais e de evangelismo, permite centralizar a administração dos recursos coletados e fazer investimentos caros e estratégicos, como a abertura de novas congregações e frentes de evangelização, a construção de templos de grande porte, a compra de emissoras de rádio e TV, a criação de gravadoras, de editoras e de outros empreendimentos. 


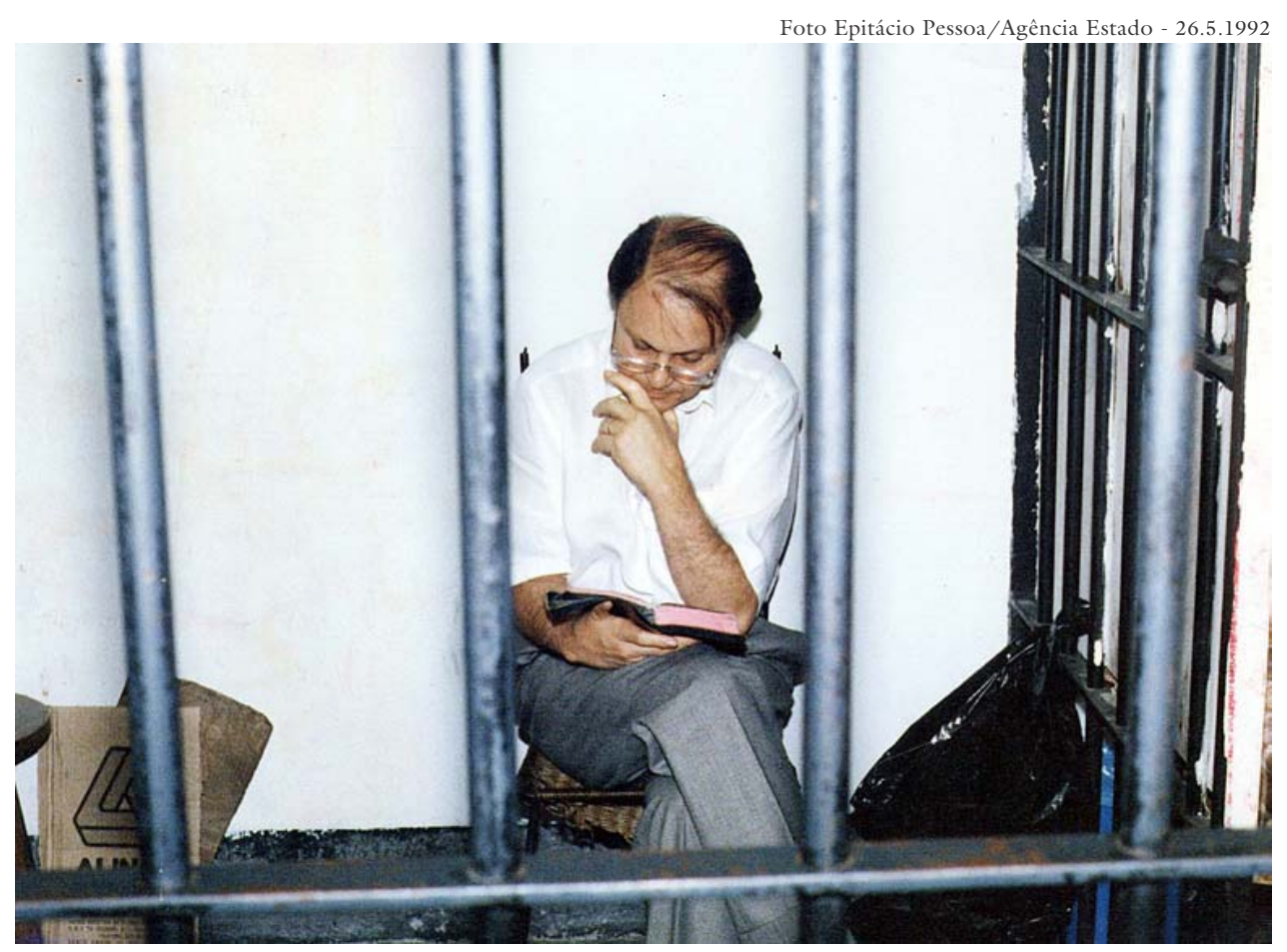

Edir Macedo ficou preso durante doze dias em cela especial do 91 a DP de São Paulo.

Apesar de eficiente, o governo vertical e centralizado coíbe inteiramente a autonomia de pastores e adeptos. Tanto que os mais de quinze mil pastores titulares e auxiliares, responsáveis pelos mais de quatro mil templos no Brasil, são remanejados freqüentemente de local de trabalho ${ }^{20} \mathrm{e}$ não gerenciam os recursos que arrecadam, enquanto os fiéis não escolhem seus líderes locais nem participam da deliberação sobre a aplicação dos dízimos e ofertas.

Para ser pastor na Universal, "os requisitos são a conversão, a dedicação e o desejo de fazer a obra de Deus. Em alguns Estados há um curso especial e intensivo com duração de seis meses, no qual o obreiro é orientado nos princípios básicos do cristianismo e da IURD”, afirma o ex-pastor José Vasconcelos Cabral ${ }^{21}$. Exigências simples e nada elitistas - conversão, dedicação e desejo - facilitam a formação de novos pastores e aceleram o ingresso dos candidatos ao trabalho pastoral. Segundo Cabral, o aprendizado para exercer o pastorado ocorre mediante "a atuação prática e direta nas igrejas". De forma que, para o aspirante a pastor, basta aprender a reproduzir corretamente o que os pastores titulares fazem no púlpito. Para avançar na hierarquia eclesiástica, precisam demonstrar elevada capacidade de coletar dízimos e ofertas, habilidade tida como sinal de bênção divina.

A denominação, cumpre frisar, manteve por alguns anos a Faculdade Teológica Universal do Reino de Deus (Faturd), que funcionava no Rio de Janeiro e oferecia cursos básico (com três anos de duração) e de bacharelado em teologia (quatro anos). Mas ela foi extinta quando Macedo se deu conta de que, para atingir seus ambiciosos objetivos expansionistas, a formação teológica, além de 
inútil, provavelmente dissiparia o tempo dos pastores, diminuiria seu fervor e os distanciaria dos interesses concretos e das necessidades imediatas dos fiéis. Ele não apenas extinguiu a faculdade teológica como, para demonstrar sua aversão à erudição teológica, publicou $A$ libertação da teologia, livro em que critica o "cristianismo de muita teoria e pouca prática; muita teologia, pouco poder; muitos argumentos, pouca manifestação; muitas palavras, pouca fé” (Macedo, s/d, pp. 11 e 128). Perspectiva compartilhada por seu cunhado Soares, para o qual "os melhores pastores não saem dos seminários". "Pastor", a seu ver, "é que nem jogador de futebol. Eles não saem das escolinhas; eles surgem, aparecem. Depois, só precisam ser lapidados" ${ }^{22}$. Para Macedo e Soares, o bom pastor é aquele que propicia os melhores resultados numéricos e financeiros à igreja.

Em contraste com o que se verifica na maioria das igrejas pentecostais, a Universal abre seus templos religiosamente todos os dias para a realização de três a quatro cultos públicos. Para manter essa "máquina" funcionando num tal ritmo de linha de produção, seus pastores trabalham em período integral, dedicando-se exclusivamente à denominação. Vínculo e compromisso institucionais que constituem enorme vantagem competitiva em relação às outras igrejas pentecostais, cujos pastores, majoritariamente, exercem outras atividades profissionais. A Universal, além disso, conta com o trabalho cotidiano de dezenas de milhares de obreiros voluntários, que desempenham tarefas cruciais para garantir o bom funcionamento dos cultos e da evangelização pessoal.

Outro fator importantíssimo do acelerado crescimento da Universal consiste em sua acentuada capacidade de arrecadar recursos, superior à das demais igrejas, como comprovam dados da pesquisa Novo Nascimento, realizada no Grande Rio de Janeiro pelo Instituto Superior de Estudos da Religião. Ao indagar os fiéis sobre a contribuição financeira que fizeram num determinado mês de 1994, a pesquisa do Iser revelou que os adeptos da Universal contribuíam mais e em maior proporção do que os da Assembléia de Deus: 27\% dos fiéis da Universal fizeram doações que ultrapassaram o valor do dízimo contra apenas $14 \%$ dos assembleianos; $17 \%$ dos seguidores de Macedo doaram quantias menores que o dízimo contra $25 \%$ da Assembléia; $24 \%$ dos primeiros não deram contribuição alguma contra $33 \%$ (um terço) dos últimos; houve empate apenas entre os que contribuíram valor equivalente ao dízimo: $24 \%$ e 23\%, respectivamente (Fernandes, 1996, p. 39). Entre as igrejas pesquisadas pelo Iser, os fiéis da Universal foram os que mais contribuíram com valores acima do dízimo, os que menos fizeram doações inferiores ao dízimo e, apesar da baixíssima renda da maioria deles, os que menos deixaram de contribuir. Cabe destacar que, dos crentes cuja renda não ultrapassava dois salários mínimos, os da Universal foram os que mais doaram quantias superiores à décima parte de sua renda: $35 \%$ contra $20 \%$ da média dos evangélicos. Quanto a essa disparidade, observa-se que pastores da Universal ensinam a seus adeptos que eles devem doar dízimos com base na renda que desejam receber, que é, em geral, superior a que recebem de fato. 
A eficiência arrecadadora da Universal se deve em grande parte à sua agressividade, insistência e incomparável habilidade persuasiva nessa matéria. Quem não paga o dízimo, advertem os pastores, rouba a Deus, que, na condição de dono de todas as riquezas existentes, exige de volta $10 \%$ dos recursos que concede aos seres humanos. Dinheiro que deve ser empregado cabalmente na realização da obra de evangelização. Essa concepção se alia à crença de que só alcança bênçãos quem tem fé. No caso, ter fé significa crer piamente no que os pastores pregam e agir conforme os ditames dessa pregação. Para provar a própria fé e granjear as recompensas decorrentes do exercício dessa virtude teologal, os fiéis são induzidos a realizar sacrifícios ou desafios financeiros. Como o tamanho da fé se mede pelo maior ou menor risco que assume no ato de doação, quem deseja demonstrar elevada fé precisa assumir grandes riscos financeiros ou realizar grandes desafios. Até porque, promete-se, quanto maior o desafio, maior a retribuição divina. Para quem não é obreiro nem desempenha funções eclesiásticas, exercer tal fé significa fundamentalmente dar dízimos e ofertas à igreja, legítima representante e fiel cumpridora dos desígnios de Deus na terra. É por meio dessa fé que o crente se torna, nos termos de Edir Macedo, sócio de Deus e, somente nessa posição privilegiada, pode passar a desfrutar das bênçãos e promessas divinas. De sua parte, os pastores não só incentivam tal arriscada demonstração de fé como garantem que os desafios são investimentos de alto retorno. De modo que tais crenças sobre dízimos e ofertas, invariavelmente, encerram cálculos utilitários, tanto da parte de quem paga quanto da de quem recebe e administra os recursos. Na condição de dizimistas e ofertantes, os fiéis almejam adquirir e exercer o direito de cobrar do próprio Deus o pronto cumprimento de Suas promessas bíblicas: vida saudável, próspera, feliz e vitoriosa. Crença que caminha na contramão da rejeição puritana à busca de riqueza e de prazeres mundanos e do livre gozo do dinheiro, o que relega a velha escatologia pentecostal ao segundo plano. Os responsáveis pelo funcionamento dessa poderosa engrenagem de arrecadação, por sua vez, procuram dilatar crescentemente o montante dos recursos coletados para reinvesti-los na igreja, na obra de evangelização e, em certos casos, em negócios comerciais que orbitam em torno das atividades religiosas.

Arrecadar mais que as igrejas concorrentes não assegura necessariamente que a Universal angarie taxas de crescimento denominacional bem acima da média pentecostal. Para obtê-la, a Universal investe majoritariamente o montante doado pelos fiéis no evangelismo eletrônico, na aquisição de novos locais de culto, no custeio de um enorme contingente de pastores trabalhando full time, na atividade missionária e de divulgação. A ampliação de sua presença geográfica no Brasil e no exterior e de seu número de pontos de pregação, de congregações e templos é fundamental para dilatar a recepção de sua oferta religiosa pelo público e, com isso, atrair maior proporção de virtuais adeptos ou criar novas clientelas para "consumir" seus serviços mágico-religiosos. 
O proselitismo em rádio e TV constitui o mais poderoso meio empregado pela Universal para atrair rapidamente grande número de indivíduos das mais diversas localidades geográficas à igreja. Por sua capacidade ímpar de introduzir a igreja, sua mensagem e seu apelo religioso nos lares, o evangelismo eletrônico apresenta a vantagem de poder alcançar aqueles que não possuem contato ou relação de confiança, amizade e parentesco com fiéis da denominação.

As lideranças pentecostais, em geral, preferem o rádio à TV. São pelo menos três as razões dessa predileção: o menor preço de locação ou de compra das emissoras, seu baixo custo de manutenção e sua elevada audiência entre os estratos mais pobres da população. Além de demandar maior custo financeiro, o televangelismo, segundo Fonseca (1997), resulta em benefício proselista inferior ao proporcionado pelo radioevangelismo. Daí que são poucas as igrejas que optaram por concentrar a maior parte de seus investimentos em propaganda religiosa na TV. Embora seja a denominação brasileira que mais investiu na aquisição de emissoras de televisão, a Universal prioriza a evangelização pelo rádio ${ }^{23}$.

Nos programas radiofônicos, transmite prioritariamente testemunhos e promessas de bênçãos e, em segundo plano, exibe músicas de cantores e bandas evangélicos contratados por sua gravadora e mensagens pastorais, incluindo a Mensagem Amiga, do bispo Macedo. Na TV, prioriza igualmente a exibição de testemunhos de fiéis e a oferta de soluções mágico-religiosas para sanar os problemas dos telespectadores. Além de cumprirem o papel de desancar as religiões concorrentes, apontadas freqüentemente como ineficientes, demoníacas e responsáveis pelos infortúnios vivenciados pelos conversos antes de seu encontro com Cristo, os testemunhos de bênçãos recebidas funcionam como comprovação prática inegável da realização das promessas de bênçãos e milagres divinos propagandeados pela igreja. De modo que eles constituem a principal vitrine da denominação para demonstrar aos ouvintes e telespectadores o real poder da Universal de derrotar o Diabo e os males causados por ele e, por meio disso, de pôr fim aos problemas materiais e espirituais que afligem os seres humanos.

Diferentemente das igrejas cujos programas enfatizam a difusão do ensino doutrinário, ou transmitem preponderantemente sermões ou preleções teológicas, a Universal destaca o poder transformador de Deus na vida dos homens, exibindo testemunhos propagandísticos de curas, milagres, intervenções e bênçãos divinas de toda espécie. Além disso, seu evangelismo eletrônico procura funcionar como linha de transmissão das atividades realizadas nos cultos públicos, convidando insistentemente os ouvintes a comparecerem nos cultos, eventos e campanhas da igreja. Com isso, visa a atrair os ouvintes e telespectadores para os templos, locais em que poderão efetivamente ser persuadidos de que precisam ser libertos dos poderes demoníacos, de que necessitam ter um encontro com Cristo, de que devem obedecer a Deus e, por fim, permanecer na igreja como condição necessária para assegurar a salvação. 

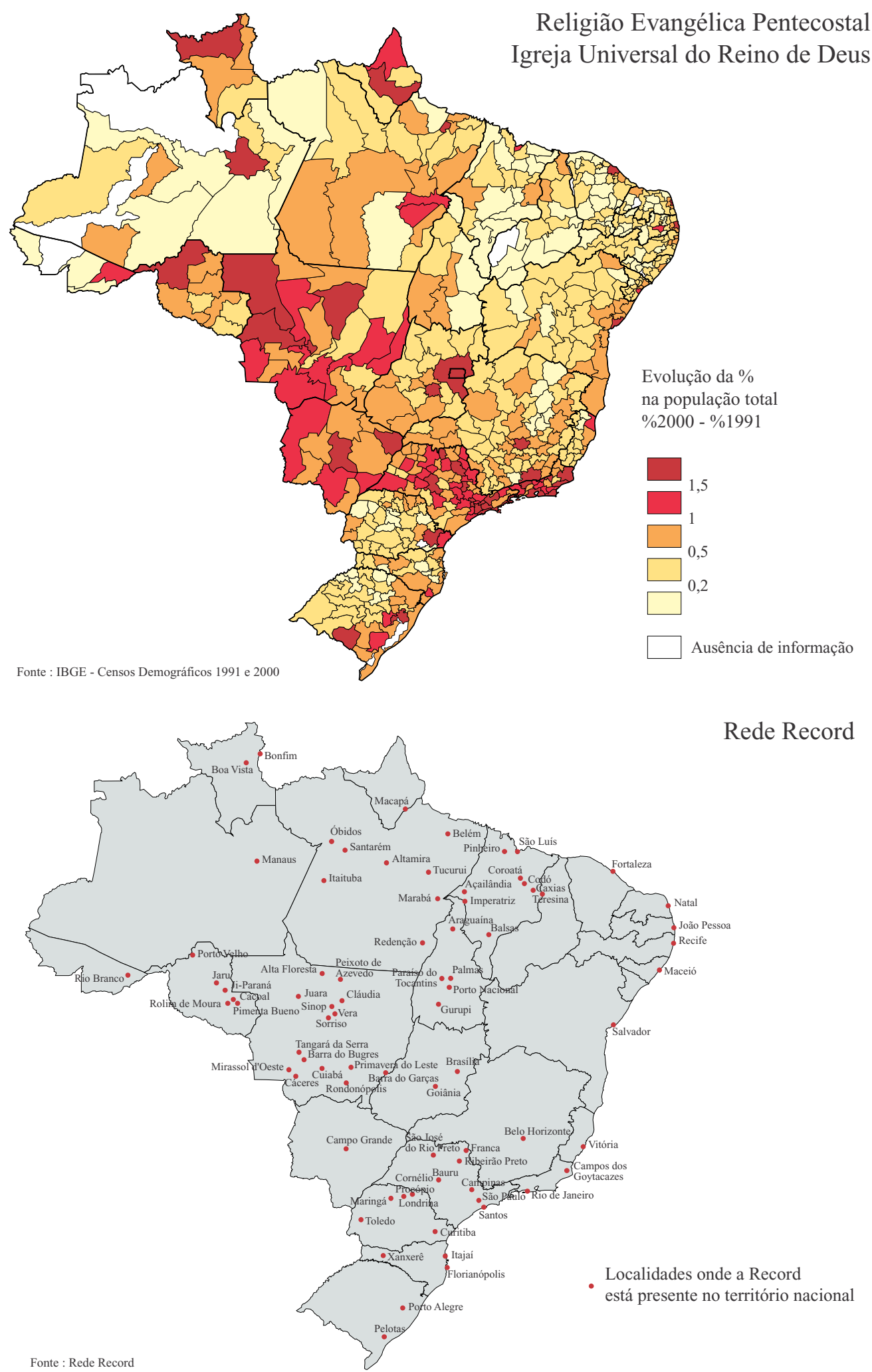
Apesar da eficácia do evangelismo eletrônico da Universal, deve-se atentar para o fato de que ele não converte praticamente ninguém, apenas atrai (o que não é pouco), em maior ou menor número, indivíduos aos templos e auxilia na implantação e divulgação de novas congregações. É no interior dos templos que a pregação ou a oferta mágico-religiosa da igreja pode se tornar plausível, isto é, romper ceticismos e barreiras que impeçam o virtual adepto de se entregar a Jesus, de mudar de religião e de se manter na nova comunidade religiosa. Seja nos casos em que atuam familiares, amigos, vizinhos, colegas de escola ou trabalho, seja naqueles em que mídia eletrônica, literatura, pregações em K7 ou em vídeo, CDs e música gospel atraem os potenciais adeptos, as relações interpessoais são cruciais na adesão à igreja e mais ainda no processo de conversão. Daí a preocupação da Universal em procurar recepcionar da melhor forma possível os recém-chegados que não possuem contato pessoal prévio com outros crentes, orientando-os didaticamente sobre a necessidade de prosseguir freqüentando os cultos e participando das correntes de oração para obter as bênçãos desejadas e, em muitos casos, inserindo-os em grupos menores e mais íntimos no interior da igreja, como os grupos de jovens, por exemplo, ou em núcleos de crentes que se reúnem na residência de um de seus membros.

Além do extenso uso da mídia eletrônica, a Universal procura maximizar a provisão de compensações concretas e imediatas ${ }^{24}$ neste mundo, adaptando sua mensagem religiosa (conteúdo, forma e meios de transmissão) à vida material e cultural das massas pobres, a fim de provê-las de sentido, significação do porquê se encontram vivendo como vivem e justificação de sua existência numa dada posição social, fornecendo-lhes recursos simbólicos e rituais para mudar subjetivamente de vida. Nesse intento, esforça-se para atraí-las, persuadi-las e recrutálas por meio da ênfase na oferta e difusão de serviços e crenças mágico-religiosos com forte apelo popular, da propaganda diuturna de testemunhos de conversão e de bênçãos materiais e do alto teor emocional dos cultos.

Pode-se observar, portanto, que a igreja optou por unir conhecimentos e aparatos tecnológicos de ponta nas áreas de propaganda e comunicação a crenças e práticas religiosas em profunda tensão com saberes, valores e instituições da modernidade. De um lado, estão as técnicas de marketing, as redes de rádio e $\mathrm{TV}$, a música, os jornais, as revistas, a literatura, a internet, de outro, os dízimos, os ritos exorcistas, as curas divinas, as promessas de milagre e de prosperidade material. Em suma: em busca de eficácia proselitista, a Universal optou por investir maciçamente em técnicas avançadas de propaganda e no evangelismo eletrônico e por dilatar e sistematizar a oferta de magia.

Não é à toa que a expansão da Igreja Universal veio reforçar ainda mais a interpretação que percebe certa continuidade entre pentecostalismo e religiosidade popular. Pois, para tirar proveito evangelístico da mentalidade e do simbolismo religiosos brasileiros, a Universal sincretiza crenças, ritos e práticas das religiões concorrentes. Faz isso de diferentes modos e em distintas ocasiões. Realiza 
"sessão espiritual de descarrego", "fechamento de corpo", "corrente da mesa branca", retira "encostos", desfaz "mau-olhado", asperge os fiéis com galhos de arruda molhados em bacias com água benta e sal grosso, substitui fitas do Senhor do Bonfim por fitas com dizeres bíblicos, evangeliza em cemitérios durante o Finados, oferece balas e doces aos adeptos no dia de Cosme e Damião. A adoção desses ritos e práticas constitui estratégia proselitista deliberada, que tem sido mantida, intensificada e até diversificada em razão de sua eficácia.

$\mathrm{Na}$ Universal, vale quase tudo para "despertar a fé das pessoas", ou para convencê-las de que a igreja prega um Evangelho de poder, que, além de verdadeiro, "funciona" na prática. As "sessões espirituais de descarrego", criadas no limiar do novo milênio, constituem um de seus mais recentes e populares experimentos sincréticos. Como se pode perceber, não se trata propriamente de culto a Deus, mas de "sessão" dedicada à imprecação de encostos ou demônios que insistem em "encostar-se" nos adeptos e na clientela da Universal. Sarcástico, o trecho abaixo, de uma matéria de jornal, ao descrever alguns detalhes das sessões de descarrego, fornece uma ligeira idéia da homologia existente entre certas crenças e práticas da Universal e as da Umbanda.

Um homem todo de branco comanda o culto, cercado por pomba-giras, exus e pretos-velhos. Os auxiliares também se vestem do branco mais puro e acreditam nos poderes do sal grosso e do galho de arruda. Que religião é essa? Ihih, se vossuncê, respondeu umbanda, está errado, mizim fio. O culto - bata a cabeça - é da Igreja Universal do Reino de Deus. Saravá. A Sessão do Descarrego - esse é o nome propagado pela própria igreja - faz sucesso às terçasfeiras, na Catedral da Fé [...]. É o momento, pregam os pastores, de retirar os encostos dos fiéis ${ }^{25}$.

Apesar de a imagem genérica em torno do sincretismo remeter-se comumente a uma suposta e tradicional tolerância religiosa dos brasileiros, a opção sincrética da Universal, cumpre frisar, não a levou a suprimir seus rompantes de intolerância nem sua notória hostilidade aos cultos afro-brasileiros. Daí uma das principais razões de seu envolvimento em diversos incidentes e conflitos religiosos ao longo dos anos ${ }^{26}$.

Nos últimos anos, a Universal, apesar de todos os percalços, conseguiu granjear maior legitimidade social e consolidar sua organização religiosa. Realizações que decorrem, em parte, da expansão de sua base demográfica e, em especial, de seu poder religioso, midiático, econômico e político.

Se fosse possível resumir as principais razões de tamanho sucesso levando em conta tão-somente o lado da oferta e, com isso, desconsiderando o contexto social, cultural, religioso e político abrangente, grosso modo, poderia se afirmar que a extraordinária expansão numérica e institucional da Igreja Universal resulta do desempenho de sua liderança eclesiástica e administrativa à frente do governo denominacional, do trabalho religioso em período integral e da eficiência de seu clero, do ativismo militante dos obreiros, do poder de atração de sua 
mensagem, do investimento em redes de comunicação e da acentuada eficácia das técnicas e estratégias de proselitismo eletrônico, da oferta sistemática de serviços mágicos adaptados aos interesses materiais e ideais de estratos pobres da população, do sincretismo de crenças e práticas mágico-religiosas em continuidade com a religiosidade popular.

Notas

$1 \mathrm{Na}$ América Latina, o termo evangélico abrange as igrejas protestantes históricas (Luterana, Presbiteriana, Congregacional, Anglicana, Metodista, Batista, Adventista), as pentecostais (Congregação Cristã no Brasil, Assembléia de Deus, Evangelho Quadrangular, Brasil Para Cristo, Deus é Amor, Casa da Bênção etc.) e as neopentecostais (Universal do Reino de Deus, Internacional da Graça de Deus, Renascer em Cristo, Sara Nossa Terra etc.). Grosso modo, o pentecostalismo distingue-se do protestantismo histórico, do qual é herdeiro, por pregar a crença na contemporaneidade dos dons do Espírito Santo, entre os quais se destacam os dons de línguas (glossolalia), cura e discernimento de espíritos, e por defender a retomada de crenças e práticas do cristianismo primitivo, como a cura de enfermos, a expulsão de demônios, a concessão divina de bênçãos e a realização de milagres.

2 Compostos majoritariamente de pentecostais, a Associação dos Homens de Negócio do Evangelho Pleno (Adhonep) e o Comitê Cristão de Homens de Negócio (CCHN), por exemplo, procuram converter empresários e profissionais liberais mediante a narração de testemunhos de bênçãos durante jantares e cafés da manhã em restaurantes e hotéis luxuosos.

3 Segundo os Censos Demográficos, os evangélicos apresentaram as seguintes taxas de crescimento médio anual entre 1940 e 1991 : 4,9\% nos anos de 1940, 4,7\% nos de $1950,5,3 \%$ nos de $1960,4,9 \%$ nos de 1970 e 4,8\% nos de 1980 .

4 No Censo 2000, 1.627.870 evangélicos $(6,2 \%$ do total) foram classificados pelo IBGE como "sem vínculo institucional" e "outros evangélicos". Embora constem na soma geral dos evangélicos, não são contabilizados nos totais de pentecostais e protestantes históricos.

5 Com base no último Censo, a Assembléia de Deus teria saltado de 2.439.770 para 8.418.154 adeptos entre 1991 e 2000, o que representa um crescimento de $14,8 \%$ ao ano. Por certo, o número de assembleianos foi subestimado no Censo de 1991, o que elevou artificialmente sua taxa de crescimento na década seguinte, taxa que não deve alcançar sequer a metade dos $14,8 \%$. Indício de subestimação pode ser observado, por exemplo, no fato de o Censo de 1991 apontar que a Assembléia de Deus tinha apenas $17,2 \%$ dos evangélicos da região Norte e meros $10,2 \%$ dos crentes do Estado do Pará, onde foi fundada. Dados improváveis, decorrentes, sobretudo, da dificuldade do IBGE em identificar a denominação de considerável parte dos evangélicos daquela e de outras regiões do país, o que levou a subestimar o montante de fiéis da Assembléia de Deus. De modo geral, pode-se afirmar que o Censo de 1991 subestimou o tamanho da maioria das principais igrejas evangélicas do país. Isso permite explicar, em parte, sua espetacular taxa de crescimento no Censo 2000. Sobre os dados de religião no Censo de 1991, ver Mariano, 2001. 
6 Cabe observar que a Congregação Cristã no Brasil se auto-exclui da política partidária e rejeita os evangelismos eletrônico, editorial e musical. Daí continuar quase invisível no espaço público, apesar de ser a segunda maior igreja pentecostal do país.

7 Para obter informações suplementares sobre o perfil demográfico e socioeconômico dos evangélicos, ver Jacob et al., 2003, pp. 39-99.

8 Sobre a classificação do pentecostalismo brasileiro, ver Freston, 1993 e Mariano, 1999.

9 No Censo 2000, a Igreja do Evangelho Quadrangular, a quinta maior denominação evangélica do país, tinha 1.318.805 adeptos, a Deus é Amor, 774.830, a Brasil Para Cristo, 175.618, e a Casa da Bênção, 128.676.

10 A Universal elegeu um deputado federal em 1986, quatro em 1990, seis em 1994, catorze em 1998 e 22 em 2002, ano em que também conquistou uma vaga no Senado, com Marcelo Crivella (PL-RJ), que se candidatou à prefeitura do Rio de Janeiro em 2004. Além de contar com dezenas de vereadores e deputados estaduais espalhados pelo país, tornou-se um importante interlocutor político, cortejado pelos mais diversos partidos, sobretudo porque tem por hábito atuar nas eleições majoritárias, conclamando seu rebanho religioso e eleitoral a apoiar certos candidatos e a desprezar outros. No segundo turno das eleições presidenciais de 2002, surpreendeu ao apoiar o candidato do Partido dos Trabalhadores, após a derrota, no primeiro turno, do evangélico Garotinho.

11 Dados obtidos em listas de endereço de templos contidas na revista Plenitude, da Igreja Universal.

12 No Censo 2000, a Universal tinha 350 mil adeptos no Estado do Rio de Janeiro, 240 mil em São Paulo, 83 mil em Belo Horizonte e 75 mil em Salvador (Jacob et al., 2003, p. 42).

13 Sobre sua implantação, presença e atuação nos demais países, ver Oro, Corten e Dozon, 2003.

14 Sobre a formação da Igreja Universal, ver Freston, 1993; Mariano, 1999, Campos, 1996 e Kramer, 1999.

15 R. R. Soares, cunhado de Macedo e líder inicial da Universal, saiu da denominação para fundar a Internacional da Graça de Deus, em 1980. Outro fundador dissidente foi Roberto Augusto Lopes, que retornou à Igreja de Nova Vida, em 1987. Deputado federal na Constituinte, Lopes foi o primeiro parlamentar eleito pela Universal para o Congresso Nacional.

16 A Universal é proprietária de várias empresas: TV Mulher, Rede Record (com 63 emissoras, sendo 21 delas próprias), 62 emissoras de rádio no Brasil, Gráfica Universal (que publica a Folha Universal, cuja tiragem semanal supera a cifra de 1,5 milhão de exemplares), Editora Universal Produções, Ediminas S/A (que edita o jornal Hoje em Dia, de Belo Horizonte), Line Records (gravadora), Uni Line (empresa de processamento de dados), Construtora Unitec, Uni Corretora (seguradora), Frame (produtora de vídeos), New Tour (agência de viagens), entre outras. No exterior, a Universal possui emissoras de rádio e TV e instituições financeiras. Sobre as empresas de comunicação da Universal, ver Fonseca, 2003.

17 Por diversas vezes nos anos de 1990, o então presidente da Associação Evangélica 
Brasileira (AEVB), pastor Caio Fábio, criticou a "liderança inescrupulosa, hostil, xiita do bispo Macedo", as "superstições pagãs" e os "manipulativos e abusivos" métodos de arrecadação da Universal, que, para ele, constrangiam e envergonhavam "o povo evangélico".

18 A cúpula da Universal tinha vários motivos para atacar a Globo nessa época. Haja vista que, não satisfeita em questionar a eficácia das curas, dos exorcismos e das promessas da Universal, em denunciar sua coleta de dízimos e ofertas por meio de uma câmara escondida e em divulgar diversas vezes o vídeo de Carlos Magno, a Rede Globo produziu e exibiu uma minissérie cujo protagonista era uma caricatura malfeita do bispo Macedo. Escrita por Dias Gomes, Decadência foi ao ar em setembro de 1995, tendo como personagem principal pastor dom Mariel, líder da Igreja da Divina Chama, enriquecido às custas da exploração financeira dos fiéis, aos quais prometia: "Venham encher os cofres de Jesus. O que vocês derem, receberão em dobro".

19 Em 2003, a Universal tinha 81 templos ativos em treze Estados norte-americanos (Kramer, 2003, p. 71).

20 Com esse rodízio de pastores nos templos locais, a cúpula eclesiástica tenta evitar que eles fidelizem os membros da congregação a seu comando pessoal, o que pode gerar cisões.

21 Vinde, n. 10, ago. 1996.

22 Eclésia, 67, jun. 2001.

23 Sobre a relevância da mídia eletrônica na expansão institucional da Igreja Universal, ver Campos, 1996; Oro, 1996, pp. 66-70; Fonseca, 1997 e Mariano, 1999, pp. 6669.

24 Stark e Bainbridge (1996, pp. 36-42) empregam o conceito de compensador para fazer a distinção entre magia e religião. Para tanto, distinguem os compensadores específicos dos compensadores gerais. Os primeiros, que caracterizam a magia, referem-se à oferta de graças pontuais, tais como, por exemplo, cura divina e melhora da auto-estima, que podem ser avaliadas e refutadas empiricamente pela experiência. Daí o alto risco assumido pelos grupos que enfatizam a oferta de serviços mágicos, uma vez que suas crenças e práticas podem ser mais facilmente desacreditadas. Já os compensadores gerais, em contraste, privilegiam a promessa de bênçãos e a difusão de crenças, tais como vida após a morte, salvação eterna, existência do paraíso celestial e do inferno, cuja veracidade não pode ser verificada nem refutada pela experiência ou pela ciência. Na prática, os grupos religiosos tendem a oferecer ambos os tipos de compensadores, só que em doses diferentes. Assim, dependendo da ênfase num ou noutro tipo de compensador, uns serão mais mágicos, outros, mais religiosos. A religião tende a gerar compromissos mais estáveis e duradouros do que a magia, cujas ofertas e promessas são mais efêmeras e baseadas numa relação de troca imediatista.

25 O Dia online, 6/8/2001 (www.odia.ig.com.br/geral/ge060815.htm).

$26 \mathrm{O}$ principal incidente religioso protagonizado pela Universal, sem dœvida, foi o famigerado "chute na santa". Em 12 de outubro de 1995, dia do feriado nacional de Nossa Senhora Aparecida, a Rede Record exibiu culto no qual bispo Sérgio Von 
Helde tocou com os pés e os punhos a imagem da santa católica - padroeira do Brasil-, escarneceu de sua ineficácia, arrastou-a pelo palco e a qualificou de "boneco feio, horrível e desgraçado". Reproduzidas a exaustão pelas TVs brasileiras, as imagens do "chute", tratadas por órgãos da imprensa como indício de "guerra santa", provocaram forte comoção nacional, reprovação unânime, deflagrando manifestações generalizadas de repœdio ao referido ato de intolerância religiosa.

Bibliografia

CAMPOS, Leonildo Silveira. Teatro, templo e mercado: uma análise da organização, rituais, marketing e eficácia comunicativa de um empreendimento neopentecostal-Igreja Universal do Reino de Deus. Tese de Doutorado, São Bernardo do Campo, Imes, 1996.

FERNANDES, Rubem César. Novo Nascimento: os evangélicos em casa, na igreja e na política. Rio de Janeiro, Iser, 1996 (mimeo.).

FONSECA, Alexandre Brasil. Evangélicos e mídia no Brasil. Rio de Janeiro, Dissertação de Mestrado, Rio de Janeiro, IFCS-UFRJ, 1997.

"Igreja Universal: um império midiático". Em ORO, Ari Pedro; CORTEN, André e DOZON, Jean-Pierre (orgs.). Igreja Universal do Reino de Deus: os novos conquistadores da fé. São Paulo, Paulinas, 2003.

FRESTON, Paul. Protestantes e politica no Brasil: da Constituinte ao impeachment. Tese de Doutorado, Campinas, IFCH-Unicamp, 1993.

JACOB, Cesar Romero et al. Atlas da filiação religiosa e indicadores sociais no Brasil. São Paulo, Loyola, 2003.

KRAMER, Eric W. Possessing faith, commodification, religious subjectivity, and collectivity in a Brazilian neo-pentecostal church. Tese de Doutorado, Chicago, Departamento de Antropologia da Universidade de Chicago, 1999.

. "A expansão da Igreja Universal do Reino de Deus nos Estados Unidos". Civitas: Revista de Ciências Sociais, vol. 3, n. 1, jun. 2003, pp. 69-96.

MACEDO, Edir. A libertação da teologia. Rio de Janeiro, Universal Produções, s/d.

MARIANO, Ricardo. Neopentecostais: sociologia do novo pentecostalismo no Brasil. São Paulo, Loyola, 1999.

Análise sociológica do crescimento pentecostal no Brasil. Tese de Doutorado, São Paulo, FFLCH-USP, 2001.

ORO, Ari Pedro. Avanço pentecostal e reação católica. Petrópolis, Vozes, 1996.

ORO, Ari Pedro; CORTEN, André e DOZON, Jean-Pierre (orgs.). Igreja Universal do Reino de Deus: os novos conquistadores da fé. São Paulo, Paulinas, 2003.

STARK, Rodney e BRAINBRIDGE, William Sims. The Future of Religion. New Brunswick, Rutgers University Press, 1985. 
RESUMO - O ARTIGO discorre inicialmente sobre o crescimento pentecostal e a evolução desse movimento religioso no Brasil. Em seguida, analisa a expansão da Igreja Universal do Reino de Deus, priorizando a investigação da organização eclesiástica, do trabalho pastoral, da capacidade de arrecadação e administração dos recursos coletados, do evangelismo eletrônico, da oferta sistemática de serviços mágico-religiosos e do sincretismo deliberado com a religiosidade popular.

ABSTRACT - THIS ESSAY deals initially with the growth of the Pentecostal movement and its evolution in Brazil. It also analyzes the expansion of the Universal Church of the Kingdom of God, prioritizing the study of its ecclesiastical organization, pastoral work, collection capabilities and management of resources thus obtained, electronic evangelism, the systematic offering of magical/religious services, and the deliberate syncretism with popular religiousness.

Ricardo Mariano é doutor em sociologia pela FFLCH-USP e professor do Programa de Pós-Graduação em Ciências Sociais da Pontifícia Universidade Católica do Rio Grande do Sul (PUC-RS).

Texto recebido e aceito para publicação em 29 de setembro de 2004. 